DOI: https://doi.org/10.46630/phm.12.2020.38

Анђела Д. Васиљевић

Оригинални научни рад

Универзитет у Београду

УДК $811.133 .1^{\prime} 37$

Филолошки факултет ${ }^{2}$

$811.163 .41^{`} 37$

Катедра за романистику

Примљен: 29. 3. 2020.

\title{
СЕМАНТИЧКА АНАЛИЗА ЛЕКСЕМЕ FOYЕR У ФРАНЦУСКОМ ЈЕЗИКУ И ЊЕНИ СРПСКИ ЕКВИВАЛЕНТИ
}

\begin{abstract}
У раду се спроводи семантичка анализа француске лексеме foyer и њених српских еквивалената. Будући да је реч о лексеми која припада општем лексичком фонду, као и да се њено примарно значење 'огњиште' односи на егзистенцијално, културолошки и социолошки важан појам у историји човечанства, очекивано је одликује богат семантички садржај. Најпре се пружа осврт на њен историјски развој, како на фонолошком, тако и на семантичком плану, успостављањем паралела са одговарајућим српским еквивалентима, које се увиђају на неколико нивоа. Затим се посредством контрастивне, компоненцијалне и квалитативне методе врши анализа грађе ексцерпиране из етимолошких (DUBOIS, MITTERAND et al. 2007; GREIMAS 1987; SKOK 1971-1974), једнојезичних (RMS, RSJ, TLF) и двојезичних речника (PUTANEC 2003; STRUGAR 1998) датих језика, у циљу утврђивања значењских еквивалената у зависности од фактора комуникативне ситуације. Посебна се пажња посвећује механизмима проширења основног значења, из ког се потом развијају нове употребне вредности посредством различитих аналошких веза. Напослетку, за сваку од уочених значењских компоненти предлажу се контекстуализовани упарени примери на француском и српском, преузети из база паралелних електронских корпуса (PARCOLAB, FRANCUSKO-SRPSKI KORPUS 2012) и веб-сајтова.
\end{abstract}

Кључне речи: лексема, foyer, огьиште, жариште, семантичка анализа, архисема, специфичне семе, полисемија, етимологија

\footnotetext{
${ }^{1}$ andjela.vasiljevic.ue@gmail.com

2 Рад представља део пројекта „Динамика структура савременог српског језика“, евиденциони број ОИ 178014, који финансира Министарство просвете, науке и технолошког развоја Републике Србије.
} 


\section{1. Увод}

\section{1. Теоријски оквир}

Механизми полисемије представљају један од најзначајнијих и најфреквентнијих начина богаћења речника (POPOVIĆ 2009: 128, 131). Просте, неизведене речи које су везане за свакодневни живот и општи лексички фонд често одликује веома богата структура семема, те оне лакше подлежу различитим семантичким трансформацијама. Уколико се забележи употреба одређене лексеме у новој комуникативној ситуацији, у другачијем контексту од уобичајеног, стварају се услови за развој секундарних значења, односно ширење њене полисемантичке структуре (GORTAN-PREMK 2004: 42, 58). Неки аутори, попут С. Улмана, полисемију доводе у везу с принципом језичке економије (ULLMANN 1952: 198). Наиме, уколико би сваки референт у ванјезичкој стварности имао посебан назив, наш когнитивни систем био би преоптерећен, што би проузроковало отежано потхрањивање нових информација у менталном лексикону (POPOVIĆ 2009: 128). У циљу превазилажења опасности од потенцијално неограниченог броја лексема, посредством бројних аналогија, долази до преноса имена с једног појма, односно референта на други, који до тада није имао адекватну деноминацију (DRAGIĆEVIĆ 2010: 130-131; GORTAN-PREMK 2004: 86-87).

\section{2. Предмет, методе и циљеви рада}

Предмет овог рада је анализа лексеме foyer, коју одликује полисемантичка структура у француском језику. У циљу испитивања механизама ширења њеног примарног значења 'огњиште', најпре се описује историјска еволуција, а затим врши анализа лексикографске обраде дате лексеме у оквиру етимолошких, једнојезичних и двојезичних речника. Посебна се пажња посвећује њеним бројним контекстуално условљеним реализацијама, те одговарајућим преводним еквивалентима у српском језику, разматрајући уједно и понашање у оквиру синтагматских и парадигматских лексичких односа. Важан циљ рада представља поређење полисемантичке структуре ове лексеме и њених српских еквивалената на контрастивном плану. Имајући у виду да је дата лексема ушла у српски језик, даје се кратак осврт на начин њене интеграције у српски фонолошки систем, те значење које је српска реплика фоаје преузела.

Применом контрастивне, квалитативне и компоненцијалне методе врши се анализа грађе ексцерпиране из једнојезичних, двојезичних и етимолошких речника француског и српског језика, као и контекстуализованих примера преузетих из електронских корпуса датих језика, те веб 
страница (в. Извори). Главни циљ рада огледа се у пружању детаљног прегледа семантичког садржаја лексеме foyer, с освртом на сличности и разлике у односу на њене српске еквиваленте.

\section{2. Историјски развој лексеме foyer}

\section{1. О латинском етимону}

Именица foyer прошла је кроз изразито сложен фонолошки развој од вулгарног латинског до савременог француског језика. Њен етимон * fŏcārǔum потиче од облика акузатива једнине супстантивираног придева fŏcārǔus, изведенице именице focus, која је у класичном латинском означавала 'огњиште' (DUBOIS, MITTERAND et al. 2007: 337). Ова лексема илуструје феномен померања значења, и то посредством механизма метонимије. У народном језику, именица focus потиснула је класични облик ignis - 'ватра/ огањ', те садржатељ почиње означавати и садржину (POPOVIĆ 2014: 19). Као резултат овог процеса, у фази која претходи развоју романских језика, именица focus добија значење 'ватра', док њена изведеница *fōcārı̌um преузима значење 'огњиште'. Облик focus у наредним вековима пролази кроз правилну еволуцију у романским језицима, дајући следеће савремене облике: фр. feu, ит. fuоco, шп. fuego, порт. fogo, рум. foc, [кат. foc] (POPOVIĆ 2014: 349).

Када је реч о еволуцији изведенице * fŏcārĭum у француском језику, уследио је сложен развојни процес, како на равни облика, тако и на равни значења, о чему говоримо у наставку рада.

\section{2. Фонолошки развој}

Једна од раних системских промена на фонолошкој равни тиче се губљења финалног [m] у вишесложним речима. Вокали у ултими, укључујући [u], до VIII века такође се престају изговарати, осим вокала [a], који је имао нешто другачији развој (POPOVIĆ 2014: 18). Иста судбина задесила је и вокале у ненаглашеној пенултими, тако да последња два слога (-i-um) нестају још у периоду који претходи коначној диференцијацији романских језика (Ibid.: 53). Иницијални ненаглашени, као и вокали у наглашеном слогу претрпели су различите промене. Лексема foyer илуструје двоструки процес дифтонгације, који обухвата иницијални ненаглашени вокал [о], односно наглашено, дуго [а].

У развоју француског језика јављају се три типа дифтонгације: спонтана, условљена и дифтонгација настала спајањем вокала (POPOVIĆ 2014: 55-65). Дата лексема показује процес условљене дифтонгације, 
која се врши како испред, тако и иза палаталних консонаната, те дифтонгацију насталу спајањем вокала. Најпре је дошло до дифтонгације дугог [a], које се нашло иза палаталног [k]. Овај се процес одвијао од VI до XIII века. Међутим, највећи део промена одиграва се током VI века, а односи се на формирање трифтонга ['́ca], чији се наглашени први елемент почиње прогресивно затварати, што доводи до свођења на дифтонг [íc] и крајњег резултата [je].

Истовремено, будући да се палатални консонант [k] нашао у интервокалном положају, најпре је дошло до његовог озвучавања у [g], те преласка у [j]. Нашавши се у интервокалном положају, консонант [j] се вокализује и заједно са претходним вокалом [о] формира дифтонг [oi], чије је исходиште у савременом француском језику дифтонг [wa], као у речима loi [lwa], roi [rwa], proie [prwa] и сл. Увид у историјску еволуцију расветљава разлог због којег се савремени дифтонг [wa] и данас бележи графијама oi, односно oy [waj] (нпр. föcārŭum > foyer ; implǐcāre >employer). Напослетку, будући да се нашао на крају речи, финални консонант [r] престаје се изговарати. Као и код поменутог дифтонга [wa], француска ортографија и данас чува његов траг.

Процес развоја лексеме foyer на фонолошком плану могуће је приказати на следећи начин ${ }^{3}$ :

*fōcārŭum $>$ [fokárijum $]>$ [fogár] $>$ [fojér] $>$ [fojíer $]>$ [foiíer $]>$ [foeiér $]>$ [fueiér] $>$ [fuejér] $>$ [fwejér] $>$ [fwejer $]>$ [fwaje] foyer.

У другим романским језицима, поменути етимон дао је следеће континуанте: шп. hogar/hoguera, порт. fogeira, ит. focaia, кат.foguer/foguera. Овај низ уједно илуструје специфичну фонетску промену која је захватила шпански језик, али не и друге романске језике: латински почетни консонант $f$ - у раној фази развоја шпанског прелази у $h$-, које потом нестаје у изговору, али се задржава у графији. Међутим, промена није системског карактера, што се види и на примеру лексема focus > fuego, где је иницијално $f$ - опстало услед присуства дифтонга [we] (KLAJN 1987: 61, 63).

\section{3. Значај концепта огњиште на цивилизацијском и културолошком плану}

Попут feu и foyer, лексеме ватра/ огањ/ огњиште и њихови бројни деривати, имају сложену полисемантичку структуру, што је умногоме последица егзистенцијалног и симболичког значаја ватре у различитим религијама, културама и друштвима. Уосталом, основни атрибути ватре, топлота и светлост, јесу „неопходни предуслови опстанка живота“, без

3 Будући да је реч о изузетно дугом, вишевековном процесу, приказане су само најзначајније етапе развоја дате лексеме. 
обзира на промене које су донели савремено доба и развој технологије (MILORADOVIĆ 2018: 113). У француском, као и у српском језику, ове лексеме су кроз историјски развој добиле нова значења мотивисана еволуцијом културе становања и људске делатности.

У римској митологији култ богиње Весте (пандан грчкој богињи огњишта, Хестији) био је изузетно поштован. Централно место у храму посвећеном Вести у Риму заузимало је управо огњиште. Света ватра која је горела у овом храму била је истовремено симбол моћи и снаге римске државе, тако да је од кључног значаја било њено одржавање, о чему су бринуле Вестине свештенице, познатије као девице Весталке (COMMELIN 1960: 31-32). Култ ватре/ огња изразито је значајан и у словенској митологији. Од давнина је заступљен у оквиру различитих породичних, пољопривредних и религијских активности и обреда. Врховни бог Словена, Перун, везује се, између осталог, за ватру, гром и муње. Многе особине приписане његовом лику опстале су у обичајима словенских народа и након примања хришћанства, што се види на примеру веровања везаних за празник Св. Илије (TOLSTOJ, RADENKOVIĆ 2001: XXIX, 65-68). Тако се у Српској православној цркви током лета празнују четири дана посвећена огњевитим свецима - Св. Прокопију, Св. Великомученици Марини (Огњеној Марији), Св. Илији (у народу најпоштованијем огњевитом свецу, господару ватре, громова, муња, кише), као и Св. Марији Магдалини (Благој Марији) -, за које се верује да штите народ и земљу од природних непогода у најтоплијем делу године (IVANOVIĆBARIŠIĆ 2007: 205-211).

У капиталној етнографској студији Ватра у обичајима и животу српског народа, С. Тројановић истиче да се кућа развила из огњишта, око којег су се примитивни народи окупљали најпре на отвореном простору, да би га потом покрили кровом, заградили са свих страна и од њега направили кућу, као „једну од највећих тековина за спокојство људско“, чије је централно и најважније место огњиште (TROJANOVIĆ 1990: 37). Како аутор запажа, из значења 'кућа' постепено се развија и ново - 'породица', о чему сведоче примери из бројних језика, између осталих, српског, грчког, те француског (Ibid.).

Латинска лексема ignis има исто порекло као и српска огањ. У питању је индоевропска, балтословенска, свесловенска, прасловенска реч, у српском језику забележена први пут у 13. веку. Обе речи настале су од истог праиндоевропског облика: „sanskr. agnis, lat. ignis < ie. *egnis ili *ngnis, prema čemu je praslav. ognb prije-voj" (SKOK II 1972: 546). Лексему огағ у савременом српском језику и другим балканским језицима, у значајној је мери заменила синонимна лексема ватра. Према појединим корпусним анализама, именица ватра данас је десет пута фреквентнија 
од синонима огағ (MILANOV 2016: 90-91). Док је у западним крајевима српско(хрватско)г говорног подручја ватра готово у потпуности потиснула огањ, чије се примарно значење данас сматра архаичним, анализа грађе ексцерпиране из призренско-тимочких дијалекатских речника показала је да су у овим говорима лексема огањ и њени бројни деривати и даље знатно заступљени. Како истиче С. Милорадовић, речи из овог деривационог поља постепено прелазе у пасивни лексички фонд и код говорника призренско-тимочког дијалекта, првенствено због значајних културолошких, технолошких и цивилизацијских промена чији смо сведоци. Међутим, према овој ауторки, барем две лексеме из датог поља опстаће у будућности, те је могуће да ће постати својеврсни језички реликти. У питању су огњиште, које ће наставити да се користи првенствено у свом секундарном значењу 'родна кућа, завичај', и Огњена Марија, народно име изузетно поштоване Свете великомученице Марине, једне од огъевитих светаца (MILORADOVIĆ 2018: 143-144).

Лексема ватра, такође индоевропског порекла, историјски се доводи у везу са латинским придевом ater, -ra, -rum - 'црн, таман'. Дати је придев у француском језику правилним развојем дао именицу âtre, коју већина речника бележи као један од синонима лексеме foyer, и то у њеном основном значењу ‘огњиште, камин’. Према П. Скоку, ватpa je „balkanska pastirska riječ, koju su i u hrv.-srp. mogli raširiti srednjovjekovni Vlasi (Joki). [...] Prvobitno riječ raširena na istoku, na zapadu samo oganj, danas rašireno i na zapad, odatle složenica (neologizam) vatrogasac, vatrogasni, vatrogastvo, prevedenica prema njem“ (SKOK III 1973: 569). У питању је лексема иранског порекла, која је још у најраније доба код овог народа потиснула стару реч за ватpy agni-, насталу од заједничког праиндоевропског облика *ognis. Према речима А. Ломе, узрок њеног потискивања првенствено је верске и обредне природе. Наиме, индоевропски народи који су сачували дату лексему у различитим облицима спроводили су обреде спаљивања мртвих, док су се Иранци оштро противили кремацији, те је ова реч добила негативну, погрдну конотацију. Из тог разлога, определили су се за реч ātar-, која се затим постепено шири међу словенским народима у југоисточним крајевима, паралелно с преузимањем иранског обреда укопавања мртвих (LOMA 2005: 21-22).

\section{3. Семантичка анализа}

\section{1. Структура семема и основне семантичке реализације}

Најопширније информације о семантичким реализацијама ове лексеме у француском језику дају једнојезични речници општег типа. 
Анђела Д. Васиљевић

Речник Trésor de la Langue Française informatisé $e^{4}$ (у даљем тексту TLF) у електронској форми пружа исцрпну лексикографску обраду лексеме foyer, те у наставку доносимо њену анализу.

Семем лексеме foyer садржи три примарна значењска елемента, у оквиру којих се реализују бројна подзначења, настала посредством различитих механизама полисемије:

I. - Lieu où l'on fait du feu. 'Место на коме се пали ватра'

II. - Lieu servant d'abri à des personnes. 'Место које служи као склониште'

III. - Source d'un rayonnement. 'Извор светлости/ зрачења'

Када је реч о првим писаним сведочанствима, извори варирају. Према речнику Dictionnaire étymologique \& historique du français, облик fuier први је пут забележен у писаним текстовима у XII веку (1131. године у епској песми Couronnement Louis), у првом значењу 'огњиште' (DUBOIS, MITTERAND et al. 2007: 337). C друге стране, речник Dictionnaire de l'ancien français jusqu'au milieu du XIVE siècle најпре наводи употребу глагола foer крајем XII века, у значењу 'запалити ватру, загрејати', али овај облик ишчезава у наредним вековима. Исти извор пружа информације о двема именицама са графијама foee ('ватра, цепаница') и foier ('пећ'). Такође, забележене су лексеме foage и foail, у значењу 'дрво за огрев', те foaille 'вунена тканина која штити од хладноће', које нису опстале у модерном француском језику (GREIMAS 1987: 290). Друго значење, 'место које служи као склониште, дом', по први се пут јавља у писаним сведочанствима из XVI века, а треће ('извор светлости/ зрачења') средином XVIII века (DUBOIS, MITTERAND et al. 2007: 337; TLF). Остала значења добијена су посредством различитих механизама полисемије.

\section{2. Творбени потенцијал}

Већина изведеница лексеме foyer није опстала у савременом језику, тако да је не одликује висок творбени потенцијал. Ретке савремене лексеме с којима је у творбеној, односно етимолошкој повезаности јесу придев focal, -e, -aux, именице focus и focalisation, као и глагол focaliser. Међутим, просечни говорник француског језика би, без познавања етимологије, тешко могао уочити повезаност ових речи са основним значењем лексеме foyer. Поменуте изведенице специјализовале су се првенствено у домену физике/ оптике, а развиле су се и њихове бројне фигуративне реализације, присутне у многим језицима, укључујући и српски (нпр. focaliser l'attention 'фокусирати пажњу'). Потребно је истаћи да су лексеме попут focal, focaliser и focalisation, за разлику од foyer, учене, а не наслеђене речи из народног језика. Наслеђене речи прошле су кроз

${ }^{4}$ Доступно на: http://atilf.atilf.fr/ 
значајну еволуцију на фонолошком, морфолошком и семантичком нивоу, док су учене тек касније укључене у француски језик, претрпевши промене мањег обима (POPOVIĆ 2009: 17).

\section{3. Примарно значење 'огњиште, огањ/ ватра'}

Како наводи TLF, историјски прво значење лексеме foyer одговара српској 'огњиште' и тада за синоним има именицу âtre, којом се упућује на део камина у коме гори ватра (пример 1). Дати чланак пружа корисне информације о понашању у синтагматским низовима, при чему предњаче описни придеви који упућују на величину и изглед огњишта (foyer étroit, grand, large [...] pierre du foyer ; coin du foyer), те сродне лексеме из генеричког поља речи $f e u /$ 'огањ/ ватра', која функционише као архилексем: braises, bûches, cendres du foyer ; feu, flamme du foyer [...]. Механизмом сужавања основног значења, добија се и значење 'жариште' (нпр. место на коме пожар избија и са кога се даље шири: foyer d'incendie). У речницима француског језика механизам сужавања значења најчешће се бележи скраћеницама spéc./ spécialt. (POPOVIĆ 2009: 133).

1) Une haute cheminée, vaste foyer dans lequel ê̂t pu brûler un chêne ou rôtir un bœuf, occupait tout un panneau du parloir et faisait face à une fenêtre à treillis, dont les vitraux peinturlurés tamisaient doucement les rayons du jour. FSK : 798755

Високи камин са пространим огњиштем, у коме би могао изгорети ияели храст или би се могао испећи во, заузимао је целу једну страну гостинске собе и налазио се према прозору са решетком, чија су обојена стакла нежно ублажавала светлост дана. FSK

Посредством метонимије, садржатељ ('огњиште') почиње означавати и саму садржину ('ватра/ огањ'), те foyer постаје синоним лексеме feu, од које је историјски настао (лат. focus- + -ārium $>$ * fŏcārĭum $>$ foyer). Синтагматски низови типични за ову семантичку реализацију укључују описне придеве и релативне реченице које упућују на изглед и интензитет ватре, односно пламена: foyer brûlant, flamboyant, incandescent ; foyer qui éclaire, qui s'éteint ; ardeur, clarté, lueur, pétillement du foyer.

Слично, лексема foyer добија бројне метафоричке вредности, нпр. foyer de l'amour, de la passion, de la civilisation ('извор/ жариште љубави, страсти, цивилизације'). Будући да није у питању лексикализована, односно мртва метафора, коју одликује окамењена, устаљена структура елемената (LANDHEER 2002: 4), број лексема са којима foyer може улазити у синтагматске односе веома је велики, те нова фигуративна значења свакодневно настају. 
Анђела Д. Васиљевић

\section{4. Секундарно значење 'склониште, дом, породица, боравиште'}

Ширењем значења (скраћеница у речнику par ext./ extension), ова лексема добија нове семантичке реализације, које се могу поделити у две велике категорије (TLF):

1. Lieu où habite, où vit une famille : 'место на коме живи породица - (породични) дом/ кућа' (примери 2 и 3). Именица foyer комбинује се са другим лексемама из лексичког поља 'породица', које углавном имају позитивну конотацију, указујући на сигурност (родитељског) дома, као и на радост због повратка кући: foyer domestique, maternel, paternel ; humble, pauvre foyer ; la douceur, les joies du foyer ; le gardien du foyer ; femme, mère au foyer [...] ; le retour au foyer ; retourner au foyer ; retrouver son foyer. Синтагматски спој le retour au foyer (као и његове варијанте retourner au foyer ; retrouver son foyer) илуструју метонимијску везу деоцелина. Овај тип односа у литератури често се тумачи као механизам синегдохе, будући да се делом 'огњиште' означава целина 'дом' (POPOVIĆ 2009: 136). Коначно, посредством датог механизма, развија се и значење famille - ‘породица'. TLF уз значење 'породица, кућа, дом' даје и важну напомену: уколико је у датом контексту именица foyer у множини, јавља се значење pays natal, patrie - 'отаџбина, домовина': réintégrer ses foyers.

(2) "Cela signifie que les regroupements extérieurs, les réunions familiales ou amicales ne seront plus permises. Se promener, retrouver ses amis dans le parc, dans la rue, ne sera plus possible. Il s'agit de limiter au maximum ses contacts au-delà du foyer. " (Allocution télévisée du président de la France, M. Emmanuel Macron, face à la propagation du COVID-19, le 16 mars 2020). „То значи да окупьаға на отвореном, окупьаға у кругу породице или пријатеља вите неће бити дозвољена. Шетьа, виђање са пријатељима у парку или на улищи, више неће бити могући. Потребно је максимално ограничити све контакте изван дома/места становања. " (Телевизијско обраћање г. Емануела Макрона, председника Француске, поводом ширења вируса COVID-19, 16.3.2020. године). ${ }^{5}$

Употребљена у значењу 'дом, место становања', именица foyer функционише као архилексем за лексеме које припадају истом генеричком пољу, као што су bâtiment 'грађевина', immeuble 'зграда', maison 'кућа', résidence 'резиденција, место боравишта', baraque 'барака', masure 'страћара', hôtel 'хотел', chalet 'летњиковац', château 'замак', palais 'палата' итд. (POPOVIĆ 2009: 170). Иако се ове именице значајно разликују по питању специфичних сема које садрже, већина разлика може се неутралисати употребом лексеме foyer, која у значењу 'дом, место становања' има статус хиперонима.

\footnotetext{
${ }^{5}$ Превод је наш.
} 
(3) Les sociologues savent pourtant que le recours à cette forme de soustraitance fragilise l'individu et dans son travail et dans son foyer. FSK : 991588 Па ипак, сочиолози знају да прибегавање овој врсти рекламе не доприноси успешности јединке, ни на послу ни у кућним обавезама. FSK

2. Lieu de réunion, d'asile pour certaines personnes : 'место окупљања, боравка, дом, азил' : foyer populaire, rural ; foyer de jeunes travailleurs, du soldat; foyer d'accueil et d'hébergement.

Првобитно значење '(породични) дом' временом почиње означавати места окупљања и привремена боравишта различитог типа: foyer d'étudiants 'студентски дом', foyer touristique 'одмаралиште', foyer culturel 'дом културе', foyer de l'enfance 'дом за децу (без родитељског старања)' и сл.

Уколико је из претходног контекста јасно о каквом је типу места боравишта реч, често се изостављају други чланови синтагматског низа (4):

(4) Pendant la guerre, au cours de la quatrième offensive exactement, nous avons fait passer par ici toute une colonne d'enfants, tous réfugiés ou orphelins d'un foyer situé sur le territoire libéré par les partisans. PARCOLAB : Branko Tchopitch : Un jardin couleur de mauve

У рату, баш у четвртој офанзиви, ми смо овуда водили читаву колону дјеце, све избјеглице и сирочад из једног дома на слободној партизанској територији. PARCOLAB: Бранко Ћопић: Башта сљезове боје

Такође, foyer се специјализује у домену позоришта, означавајући место где се окупљају глумци (foyer des acteurs, des artistes), односно публика (foyer du public), како би се одморили и освежили на паузама. Употребљена у овом значењу дата лексема усталила се и у српском језику. Једнотомни Речник српскога језика (RSJ) пружа следећу дефиницију одреднице фоаје:

фоаје, -еа м фр. просторија, дворана у позоришту,

биоскопу итд., у којој се окупљају посетиоци

пре почетка представе или за време паузе, предворје.

Приликом уласка у српски језик, најпре се врши прилагођавање на фонолошком нивоу. Као и у случају већине галицизама који садрже дифтонг /wa/ у комбинацији са /j/ у интервокалном положају (графија 'оу'), долази до адаптиране секвенце /oaj/: doyen [dwajẽ ] doajen; foyer [fwaje] $>$ foaje; plaidoyer [pledwaje] > pledoaje. Међу ретким изузецима од овог правила јављају се лексеме loyal и royaliste, код којих се секвенца /waj/ ипак адаптира као /oj/: лојалан, ројалист (POPOVIĆ 2005: 43).

Позивајући се на типологију адаптације значења француских позајмљеница у руском, коју је установио Ж. Мартиновски, М. Поповић разликује пет типова адаптације галицизама у српском језику на равни значења (Ibid.: 114-150): 
1. Подударање свих значења у моделу и реплици (нпр. mayonnaise - мајонез);

2. Сужење значења, при чему реплика преузима само одређена значења (нпр. bureau - биро);

3. Проширење значења, где се у српском језику развијају специфична значења којих нема у француском моделу (нпр. garderobe-гардероба);

4. Делимично преклапање, то јест комбинација сужења и проширења значења (нпр. estrade - естрада);

5. „Лажни пријатељи“, код којих модел и реплика немају заједничке семеме на синхронијском плану, те је веза између њих само обличка (нпр. courrier - курир).

Следећи ову шему, српска реплика фоаје илуструје феномен сужења значења, будући да из семема француског модела foyer преузима само једно од бројних значења, и то оно специјализовано за домен позоришта: salle où les spectateurs peuvent circuler, prendre des consommations pendant les entractes - 'сала у којој гледаоци могу да бораве, попију освежавајуће напитке за време одмора између представа'.

\section{5. Секундарно значење 'извор светлости, топлоте'}

Историјски најновије значење јавља се од XVIII века: point, centre d'où rayonne de la lumière, de la chaleur - 'тачка, центар одакле се шири светлост, топлота' (пример 5), из којег се путем механизама полисемије стварају нове реализације, окупљене око заједничког значењског језгра: centre d'où provient quelque chose, lieu à partir duquel se développe, se répand quelque chose - 'центар из којег потиче нешто, место одакле се нешто развија и шири'. Foyer de corruption, d'intrigues; foyer de rébellion ; foyer de civilisation, de culture - 'жариште корупције, интрига; жариште/ центар побуне; жариште цивилизације, културе'.

У питању су значења настала путем метафоре, имајући у виду да на основу аналогије долази до преношења означитеља лексеме foyer на друге означенике. Овај механизам изразито је погодан за стварање импровизованих, слободних метафора (скраћеница у речницима au fig./ au figuré), али и за терминолошке метафоре, типичне за различите језике струке.

(5) On suppose, à la place du soleil, un grand foyer lumineux, maintenant disparu, et dont les aurores boréales ne sont peut-être que les vestiges. FSK : 177111

Претпоставља се, уместо Суниа једно велико светлосно огыиште, сада ишчезло, и бореалне зоре можда су само његови трагови. FSK 


\section{6. Лексема foyer као терминолошка метафора}

У претходним деценијама, а нарочито од осамдесетих и деведесетих година прошлога века, велики број истраживања посвећен је лексикализованим, терминолошким метафорама, устаљеним у оквиру различитих научних и стручних области. Најпре је њихова улога била изједначавана са феноменом катахрезе, будући да су имале функцију попуњавања терминолошких празнина. Помаке на пољу ових истраживања несумњиво је условио развој бројних лингвистичких (интер)дисциплина, пре свега прагматике, когнитивне лингвистике, семиотике, текстуалне лингвистике и сл. Према ауторима као што су Р. Коцурек, И. Оливеира или И. Коломба, улога лексикализованих метафора вишеструко је значајна на дидактичком и комуникативном плану, те на плану научне вулгаризације, јер се терминолошке јединице настале на основу аналогија са појавама, бићима и предметима из свакодневног живота лакше усвајају (ROSSI 2014: 713-714). Како припада основном лексичком фонду и улази у различите механизме полисемије, foyer се јавља у терминологији бројних језика струке, нарочито у медицини (епидемиологији), физици (оптици) и економији.

\subsection{1. Медицина}

Дата лексема специјализовала се у домену епидемиологије, упућујући на порекло, односно жарищте (заразне) болести, било да је она увезена из иностранства, било да је домаћег порекла: Lieu où apparaissent des cas d'une maladie quarantenaire résultant de cas importés ou non. Foyer d'épidémie - 'жариште епидемије' (примери 6, 7).

(6) Au total, 1137 personnes ont guéri après avoir contracté le virus. Mais un nouveau foyer de contamination est apparu à une vingtaine de kilomètres au sud de Séoul. Les autorités ont fait état, lundi, de 46 cas au sein de cette congrégation. ${ }^{6}$

Укупно се 1137 особа опоравило након ито су заражени вирусом. Међутим, ново жариште појавило се двадесетак километара јужно од Сеула. Власти су у понедељак објавиле 46 случајева у оквиру ове конгрегације. ${ }^{7}$

(7) Un nouveau foyer de coronavirus a été identifié le 11 mars près de Rennes, à Bruz où 10 personnes au total ont été contaminées, portant le nombre de cas confirmés à 104 en Bretagne, selon l'Agence régionale de santé (ARS) et la préfecture de région. Le nombre de foyers en France s'élève désormais à neuf, comme le montre notre carte. ${ }^{8}$

\footnotetext{
${ }^{6} \mathrm{https}$ :/www.ouest-france.fr/sante/virus/coronavirus/coronavirus-la-coree-du-sud-fait-etat-de74-nouveaux-cas-des-chiffres-en-leger-declin-6781515, страница консултована 17.3.2020.

${ }^{7}$ Превод је наш.

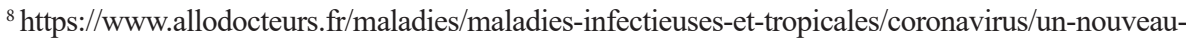
foyer-de-coronavirus-en-france_28902.html, страница консултована 17.3.2020.
} 
Ново жсариште корона вируса идентификовано је 11. марта у близини Рена, у Брију где је укупно 10 особа заражено, чиме се број потврђених случајева повећао на 104 у Бретањи, према Регионалној здравственој агенцији (АРС) и префектури региона. Број жсаришта у Франиуској сада је повећан на девет, како показује наша карта. ${ }^{9}$

Међутим, према TLF, не мора бити у питању само заразна болест, већ се лексемом foyer може означити било који извор одакле потиче бол(ест) или нека лезија, односно повреда (пример 8): Partie du corps où se trouve le siège principal d'une maladie, d'une lésion.

(8) Lors d'une dénervation, on traite également les zones voisines pour $s$ 'assurer de l'éradication du foyer de douleur. ${ }^{10}$

Приликом денерваџије, третирају се и суседне зоне како би се у потпуности отклонило порекло/ жсариште бола. ${ }^{11}$

У српском језику постоји иста ментална слика, односно терминолошка метафора везана за домен епидемиологије, али се у том случају не користи огњиште, већ лексема жариште, која такође припада генеричком пољу речи огањ/ ватра (MILANOV 2016: 97). Шестотомни Речник српскохрватскога књижевног језика (RMS) пружа следећу дефиницију одреднице 'жариште', идентификујући њену терминолошку употребу у областима физике и медицине:

жа̀риште и жаррйшта с 1. а. физ. тачка у којој се сједињују зраци после преламања кроз сочиво, лећу, жижа, фокус. б. Највиша тачка, зенит. - Наилазило и подне, доспело сунце у жариште. Рад. Д. 2. фиг. а. главно, централно место нечега, иентар. - Ту је жариште промета, особито сад у рату. Перк. Покушај да се жариште устанка у источној Босни уклони није успио. Чол. б. извор распростирања нечега: гнојно , болести, културно и сл.

\subsection{2. Физика}

Према TLF, у оптичкој терминологији лексема foyer односи се на фокус, односно жижу: Point constitué par le sommet du faisceau conique formé par la réflexion ou la réfraction de rayons lumineux initialement

\footnotetext{
${ }^{9}$ Превод је наш.

${ }^{10} \mathrm{https} / /$ www.linguee.fr/francais-anglais/traduction/foyer+de+douleur.html, страница консултована 17.3.2020.

${ }^{11}$ Превод је наш.
} 
parallèles - 'Тачка коју формира врх коничног снопа, настао рефлексијом или рефракцијом почетно паралелних светлосних зрака'.

Најчешћи синтагматски спојеви ове лексеме у области оптике су foyer d'une lunette 'жижа/ фокус наочара', d'un objectif 'објектива', d'un télescope 'телескопа'; foyer réel 'стварни фокус'; foyer par réflexion 'фокусирање рефлексијом', par réfraction 'рефракцијом'. Des miroirs ou des lentilles à foyer - 'Огледала или фокусна сочива'.

Уочава се ширење лексеме и на домен акустике, мада је ова употреба забележена релативно скоро, пре нешто више од пола века: [...] emploi de foyer dans le domaine de l'acoustique au sens de "point de convergence des ondes acoustiques frappant un réflecteur parabolique ou sphérique " 'тачка у којој се спајају акустични таласи, ударајући у параболични или сферни рефлектор'.

\subsection{3. Економија и политика}

Када је реч о употреби ове именице у сфери економије, TLF бележи следеће значење: Groupement géographique d'industries, centre de commerce, etc. - 'Индустријски центри/ басени груписани на малом географском простору, трговински центар' (пример 9).

(9) L'Europe possède d'énormes foyers industriels : les produits européens submergent le monde : cette situation privilégiée est le résultat de la révolution industrielle du XIX siècle marquant le passage d'une économie de subsistance à celle de production, d'échange et de consommation de masse. ${ }^{12}$

Европа има огромне индустријске центре: европски производи преплављују свет: ова привилегована ситуачија последица је индустријске револуичје XIX века, коју је обележио прелазак са натуралне на економију производюе, размене и масивне потрошње. ${ }^{13}$

Лексема foyer јавља се и у другим областима (нпр. политици, социологији), али у највећем броју случајева још увек није дошло до лексикализације и устаљивања на терминолошком нивоу, те се такве употребе често описују као фигуративне. Двојезични Srpsko-francuski rečnik: politika, pravo, ekonomija (STRUGAR 1998: 409) као еквиваленте одреднице жариште у сфери политичке терминологије наводи лексеме centre и foyer, у значењу 'центар, упориште', пружајући неке од уобичајених синтагматских спојева који се срећу у језику дате струке: centre / foyer de guerre 'жариште/ центар рата', de conflits 'сукоба', de troubles 'нереда', d'opposition 'опозиције'.

\footnotetext{
${ }^{12} \mathrm{http}: / /$ www.encyclopedie.bseditions.fr/article.php?pArticleId=125\&pChapitreId=30484\&pS ousChapitreId $=30486 \& p$ ArticleLib $=$ Foyer + industriel $+\% 5$ BHistoire $+\% 3 \mathrm{~A}+1900 \% 2 \mathrm{C}+1 \% 92 \mathrm{E}$ urope + domine $+\mathrm{le}+$ monde- $\% 3 \mathrm{ELa}+$ puissance + europ $\% \mathrm{E} 9 \mathrm{enne} \% 5 \mathrm{D}$, страници приступљено 20.3.2020.

${ }^{13}$ Превод је наш.
} 


\section{4. Лексикографска обрада лексеме foyer у двојезичном речнику}

Када је реч о преводним еквивалентима именице foyer, Francuskohrvatski rječnik (PUTANEC 2003) даје следеће информације:

foyer [fwaje] m. ognjište, peć, ložište; komora za

sagorijevanje; grijanje, loženje; žarište, fokus;

fokusna daljina; svjetlost fara (aerodromska); izvor (zračenja); fig. ognjište, dom, zavičaj, post-

ojbina; fig. žarište, predvorje, foaje (u kazalištu i

sl.); $\approx$ de vacances odmaralište; $\approx$ culturel dom

kulture; $\approx$ touristique turistički dom

Најпре се пружа податак о основном значењу, које одговара лексемама из ономазиолошког поља речи ватра/ огағ, а потом и информације о значењима специјализованим у оквиру физике - 'fokus; fokusna daljina; svjetlost fara (aerodromska); izvor (zračenja)'. Фигуративна се значења групишу у две целине: с једне стране, она која одговарају семантичком језгру лексема 'dom, zavičaj, postojbina', и с друге, значења везана за метафоричку употребу лексеме žarište (у ширем значењу 'извор, порекло, центар нечега'). Бележи се и облик foaje, који је ушао у српск(охрватск)и језик у значењу - 'предворје (у позоришту)'. Коначно, наведена су и три честа синтагматска споја у француском: foyer culturel, foyer de vacances, foyer touristique. Сматрамо да важан недостатак ове дефиниције представља непостојање других фреквентних синтагматских спојева, нарочито оних устаљених у области медицине (епидемиологије) и економије.

\section{5. Закључна разматрања}

У раду смо предложили кратак осврт на семантичку структуру француске именице foyer и њених преводних могућности у српском језику. Пошли смо од етимолошке анализе, која је указала на постојање чврстих веза између дате лексеме и њених српских еквивалената, што је последица дубоко укорењеног концепта огањ/ ватра (огњиште) у историји човечанства. Значај овог концепта најбоље се очитује на језичком плану, на шта указује веома богата структура семема речи $f e u /$ foyer, односно ватра/ огағ/ огњиште. На творбеном плану, уочен је знатно већи потенцијал српских еквивалената. Када је реч о механизмима полисемије, у оба језика јављају се потпуно исти процеси померања, проширења, те сужења значења на основу аналошких веза (нпр. развој значења 'дом, место становања' и 'извор светлости’ из примарног 'место на коме гори 
ватра'). Значајна је и констатација да се у француском и српском развијају бројне терминолошке метафоре са компонентама foyer и огњиште/ жаpиште. Коначно, истраживањем је потврђено да су менталне представе у датим језицима идентичне. Сви поменути феномени, било да припадају свакодневном животу, језицима струке или домену апстрактног, метафорички се доводе у везу са сликом ватре, односно светлости која избија и шири се из одређеног језгра.

\section{Цитирана литература}

COMMELIN 1960 : COMMELIN, Pierre. Mythologie grecque et romaine. Édition illustrée de nombreuses reproductions. Paris : Éditions Garnier Frères, 1960. <http://classiques.uqac.ca/classiques/commelin_pierre/mythologie/ mythologie_greco_rom.pdf $>$. [15.3.2020.]

DRAGIĆEVIĆ 2010: DRAGIĆEVIĆ, Rajna. Leksikologija srpskog jezika. Beograd: Zavod za udžbenike, 2010. [orig.] ДРАГИЋЕВИЋ, Рајна. Лексикологија српског језика. Београд: Завод за уџбенике, 2010.

GORTAN-PREMK 2004: GORTAN-PREMK, Darinka. Polisemija i organizacija leksičkog sistema u srpskome jeziku. Beograd: Zavod za udžbenike i nastavna sredstva, 2004. [orig.] ГОРТАН-ПРЕМК, Даринка. Полисемија и организаиија лексичког система у српскоме језику. Београд: Завод за уџбенике и наставна средства, 2004.

IVANOVIĆ-BARIŠIĆ 2007: IVANOVIĆ-BARIŠIĆ, Milina. Kalendarski praznici i običaji u podavalskim selima. Beograd: Srpska akademija nauka i umetnosti, Etnografski institut, 2007. [orig.] ИВАНОВИЋ-БАРИШИЋ, Милина. Календарски празници и обичаји у подавалским селима. Београд: Српска академија наука и уметности, Етнографски институт, 2007.

KLAJN 1987: KLAJN, Ivan. Istorijska gramatika španskog jezika. II izdanje. Beograd: Naučna knjiga, 1987.

LANDHEER 2002: LANDHEER, Robert. « La métaphore, une question de vie ou de mort ». Semen : Revue de sémio-linguistique des textes et discours, 15 (novembre 2002) : p. 1-12. <https://journals.openedition.org/semen/2368>. [22.4.2020.]

LOMA 2005: LOMA, Aleksandar. „Stara slovenska religija: jedan lični pogled iz komparativnog ugla“. Zbornik Matice srpske za književnost $i$ jezik, knj. 53, sv. 1-3 (decembar 2005): str. 9-27. [orig.] ЛОМА, Александар. „Стара словенска религија: један лични поглед из компаративног угла“. Зборник Матице српске за књижевност и језик, књ. 53, св. 1-3 (децембар 2005): стр. 9-27.

MILANOV 2016: MILANOV, Nataša. „O značenjima leksema vatra i oganj u srpskom jeziku“. U: Mišić Ilić, Biljana i Vesna Lopičić (ur.). Jezik, književnost, 
značenje. Jezička istraživanja: zbornik radova (str. 89-100). Niš: Filozofski fakultet, 2016. [orig.] МИЛАНОВ, Наташа. „О значењима лексема ватра и огањ у српском језику“. U: Mišić Ilić, Biljana i Vesna Lopičić (ur.). Jezik, književnost, značenje. Jezička istraživanja: zbornik radova (str. 89-100). Niš: Filozofski fakultet, 2016.

MILORADOVIĆ 2018: MILORADOVIĆ, Sofija. „Oganj, pa žiška, ožeg, žar i još ponešto oko vatre u prizrensko-timočkim dijalekatskim rečnicima“. U: Piper, Predrag i Marjan Markoviḱ (ur.). Jezik kao zapis kulture u etnološkoj i lingvističkoj analizi na relaciji Srbija - Makedonija, tom 1 (str. 113-146). Beograd: Srpska akademija nauka i umetnosti, Makedonska akademija na naukite i umetnostite, 2018. [orig.] МИЛОРАДОВИЋ, Софија. „Огањ, па жишка, ожег, жар и још понешто око ватре у призенско-тимочким дијалекатским речницима“. У: Пипер, Предраг и Марјан Марковиќ (ур.). Језик као запис културе у етнолошкој и лингвистичкој анализи на релацији Србија - Македонија, том 1 (стр. 113-146). Београд: Српска академија наука и уметности, Македонска академија на науките и уметностите, 2018.

POPOVIĆ 2005: POPOVIĆ, Mihailo. Reči francuskog porekla u srpskom jeziku. Beograd: Zavod za udžbenike i nastavna sredstva, 2005.

POPOVIĆ 2009: POPOVIĆ, Mihailo. Leksička struktura francuskog jezika: morfologija i semantika. Beograd: Zavod za udžbenike, 2009. [orig.] ПОПОВИЋ, Михаило. Лексичка структура франщуског језика: морфологија и семантика. Београд: Завод за уџбенике, 2009.

POPOVIĆ 2014: POPOVIĆ, Mihailo. Istorija francuskog jezika. Beograd: Jasen, 2014.

ROSSI 2014: Rossi, Micaela. « Métaphores terminologiques : fonctions et statut dans les langues de spécitalité ». In : Neveu, Frank et Peter Blumenthal, Linda Hriba, Anette Gerstenberg, Judith Meinschaefer, Sophie Prévost (eds.). SHS Web of Conferences. Actes du $4^{e}$ congrès mondial de Linguistique françaiseCMLF 2014 (p. 713-724). Les Ulis: EDP Sciences, 2014.

TOLSTOJ, RADENKOVIĆ 2001: TOLSTOJ, Svetlana i Ljubinko RADENKOVIĆ (ur.). Slovenska mitologija: enciklopedijski rečnik. Beograd: Zepter book world, 2001. [orig.] ТОЛСТОЈ, Светлана и Љубинко РАДЕНКОВИЋ (ур.). Словенска митологија: енциклопедијски речник. Београд: Zepter book world, 2001.

TROJANOVIĆ 1990: TROJANOVIĆ, Sima. Vatra u običajima i životu srpskog naroda. Beograd: Prosveta, 1990. [orig.] ТРОЈАНОВИЋ, Сима. Ватра у обичајима и животу српског народа. Београд: Просвета, 1990.

ULLMANN 1952: ULLMANN, Stephen. Précis de sémantique française. Berne : A. Francke, 1952. 


\section{Извори (лексикографски и корпусни)}

DUBOIS, MITTERAND et al. 2007: DUBOIS, Jean et Henri Mitterand, Albert Dauzat. Dictionnaire étymologique \& historique du français. Paris : Larousse, 2007.

FSK: VITAS, Duško i Miloš UTVIĆ. Korpus savremenog srpskog jezika, verzija Francusko-srpski korpus 2012. Beograd: Grupa za jezičke tehnologije Univerziteta u Beogradu, 2012. <http://www.korpus.matf.bg.ac.rs/korpus/ login.php>. [10.3.2020.]

GREIMAS 1987: GREIMAS, Algirdas Julien. Dictionnaire de l'ancien français jusqu'au milieu du XIV siècle. Paris : Larousse, 1987.

PARCOLAB: Višejezični korpus ParCoLab. Tuluz - Beograd: Univerzitet Tuluz Žan Žores, Filološki fakultet Univerziteta u Beogradu. $<$ http://parcolab.univtlse2.fr/>. [9.3.2020.]

PUTANEC 2003: PUTANEC, Valentin. Francusko-hrvatski rječnik. IX izdanje. Zagreb: Školska knjiga, 2003.

RMS: STEVANOVIĆ, Mihailo. Rečnik srpskohrvatskoga književnog jezika, I-VI. Novi Sad - Zagreb: Matica srpska, Matica hrvatska, 1967-1976. [orig.] CTEВАНОВИЋ, Михаило. Речник српскохрватскога књижевног језика, I-VI. Нови Сад - Загреб: Матица српска, Матица хрватска, 1967-1976.

RSJ: NIKOLIĆ, Miroslav (ur.). Rečnik srpskoga jezika. Novi Sad: Matica srpska, 2007. [orig.] НИКОЛИЋ, Мирослав (ур.). Речник српскога језика. Нови Сад: Матица српска, 2007.

SKOK I, III: SKOK, Petar. Etimologijski rječnik hrvatskoga ili srpskoga jezika, I-IV. Zagreb: Jugoslovenska akademija znanosti i umjetnosti, 1971-1974.

STRUGAR 1998: STRUGAR, Novak. Srpsko-francuski rečnik: politika, pravo, ekonomija. Beograd: Udruženje naučnih i stručnih prevodilaca Srbije, 1998.

TLF : Trésor de la Langue Française informatisé. ATILF - CNRS \& Université de Lorraine. $<$ http://atilf.atilf.fr/>. [10.3. - 20.3.2020.]

http://www.encyclopedie.bseditions.fr/article.php?pArticleId=125\&pChapitre $\mathrm{Id}=30484 \&$ pSousChapitreId $=30486 \& p$ ArticleLib $=$ Foyer + industriel $+\% 5$ BHistoire $+\% 3 \mathrm{~A}+1900 \% 2 \mathrm{C}+1 \% 92 \mathrm{Europe}+\mathrm{domine}+\mathrm{le}+$ monde- $\% 3 \mathrm{ELa}+-$ puissance+europ\%E9enne\%5D [20.3.2020.]

https://www.allodocteurs.fr/maladies/maladies-infectieuses-et-tropicales/ coronavirus/un-nouveau-foyer-de-coronavirus-en-france_28902.html [17.3.2020.]

https://www.linguee.fr/francais-anglais/traduction/foyer + de + douleur.html [17.3.2020.]

https://www.ouest-france.fr/sante/virus/coronavirus/coronavirus-la-coree-dusud-fait-etat-de-74-nouveaux-cas-des-chiffres-en-leger-declin-6781515 [17.3.2020.] 
Anđela Vasiljević

\section{ANALYSE SÉMANTIQUE DU LEXÈME FOYER ET SES ÉQUIVALENTS SERBES}

Le présent travail a pour sujet l'analyse sémantique du lexème foyer et de ses équivalents serbes. Étant donné qu'il s'agit d'un lexème appartenant au fonds lexical général, et que son acception de base « lieu où l'on fait du feu » (en serbe ognjište) fait référence à un concept existentiellement, culturellement et sociologiquement important dans l'histoire de l'humanité, foyer est doté d'un riche contenu sémantique. D'abord, nous proposons un aperçu de son évolution historique sur les plans phonologique et sémantique, tout en établissant les parallèles avec ses équivalents serbes, qui existent sur plusieurs niveaux. Ensuite, à travers les méthodes contrastive et componentielle, nous effectuons une analyse qualitative du corpus extrait de dictionnaires étymologiques (DUBOIS, MITTERAND et al. 2007 ; GREIMAS 1987 ; SKOK 1971-1974), monolingues (RMS ; RSJ ; TLF) et bilingues (PUTANEC 2003 ; STRUGAR 1998) des langues données, avec une attention particulière accordée aux spécificités de la situation communicative. Ainsi, pour chacune des acceptions identifiées, nous proposons des exemples alignés et contextualisés, provenant de sources diverses (bases textuelles et sites Internet).

Mots-clés : lexème, foyer, ognjište, žarište, analyse sémantique, archisème, sèmes spécifiques, polysémie, étymologie 